\title{
A General Strategy for the Preparation of Thalidomide-Conjugate Linkers
}

\author{
J. W. Papatzimas a\# \\ E. Gorobets ${ }^{\text {a\# }}$ \\ D.K. Brownseya \\ R. Maityb \\ N. J. Bahlis ${ }^{b}$ \\ D. J. Derksena*
}

${ }^{a}$ Department of Chemistry, University of Calgary, 2500 University Drive NW, Calgary, Alberta, Canada, T2N 1N4.

${ }^{b}$ Department of Hematology and Oncology, University of

Calgary, Calgary, Alberta, Canada, T2N 4N1.

* indicates the main/corresponding author, " these authors contributed equally.

dderksen@ucalgary.ca<smiles>Cc1sc2c(c1C)C(c1ccc(Cl)cc1)=N[C@@H](CC(=O)Oc1c(F)c(F)c(F)c(F)c1F)c1nnc(C)n1-2</smiles><smiles>O=C1CCC(N2C(=O)c3cccc(OCC(=O)Oc4c(F)c(F)c(F)c(F)c4F)c3C2=O)C(=O)N1</smiles>

\section{Received:
Accepted:
Published online:
DOl:}

Abstract The synthesis of small molecule linkers for installation of thalidomide based conjugates is described. Linker properties have been recognized as vital to conjugate success in drug discovery and delivery systems. These small molecule tethers act as linkages between molecules, can also aid in cell permeability, and act as solubilizing agents. This work shows our progress in synthesizing conjugates with a variety of linker characteristics. The adaptability and manipulation of these and other linkers holds potential in improving synthetic control of chemical connectivities toward therapeutic development.

Key words PROTAC, Thalidomide, Conjugates, Linker, Pentafluorophenyl Ester

Since the seminal reports by Bradner ${ }^{1}$ and Crews $^{2}$ on the use of thalidomide conjugation for in vivo protein degradation, our group and others have become interested in the synthetic preparation of small-molecule conjugates incorporating this moiety (Scheme 1, A). ${ }^{3}$ As both linker length and composition have been shown to be essential for preparing functional conjugates,1-5 we have worked to develop a sufficiently convergent synthetic strategy to prepare multiple linkers for structure-activity relationship studies.

A recent paradigm shift in proximity directed protein degradation has seen the implementation of Proteolysis Targeting Chimeras (PROTACs) as a means of inducing protein degradation.4,6,7,8 PROTACs are small molecule conjugates which enhance proximity between proteins of interest (POIs) through bifunctional targeting conjugates to initiate protein degradation. ${ }^{4}$ Thalidomide derivatives have been successfully used as targeting ligands in previously published PROTAC work. ${ }^{12,36,9}$ Due to the importance of proximity enhancement for PROTACs, linker length between targeting molecules becomes vital to effective recruitment and positioning of POIs.

Our initial approach to thalidomide conjugates relied on a highly linear synthesis from literature where the linker moiety needed to be introduced prior to glutarimide introduction (Scheme 1, B). ${ }^{10}$ Our own attempts to improve the synthesis found that direct phenol alkylation of 4-hydroxythalidomide (1) led to competing $\mathrm{N}$-alkylation of the glutarimide moiety. We were working to make this synthesis more convergent when elegant work from Miller showed that the phenolic site of hydroxylthalidomide could be functionalized directly using modified Mitsunobu conditions (Scheme 1, C). ${ }^{11}$ This advancement allowed us to synthesize our desired compounds in a much shorter time frame by making the synthesis much more convergent.

A<smiles>[R]Oc1cccc2c1C(=O)N(C1CCC(=O)NC1=O)C2=O</smiles>

1, $\mathrm{R}=\mathrm{H}$

2, $\mathrm{R}=$ Linker

3, $\mathrm{R}=\mathrm{CH}_{2} \mathrm{CO}_{2} \mathrm{Bn}$<smiles>COC(=O)c1c(O)cccc1OCC(C)C</smiles><smiles>O=C1CCC(N2C(=O)c3cccc(O)c3C2=O)C(=O)N1</smiles><smiles>[X]CCNC(=O)COc1cccc2c1C(=O)N(C1CCC(=O)NC1=O)C2=O</smiles>

Scheme 1. 4-hydroxythalidomide derivative syntheses. $\mathrm{X}=\mathrm{CH}_{2}$ or $\left(\mathrm{CH}_{2}\right)_{2} \mathrm{C}(\mathrm{O}) \mathrm{NH}\left(\mathrm{CH}_{2}\right)_{3}\left(\mathrm{O} \mathrm{CH}_{2} \mathrm{CH}_{2}\right)_{3}$. 


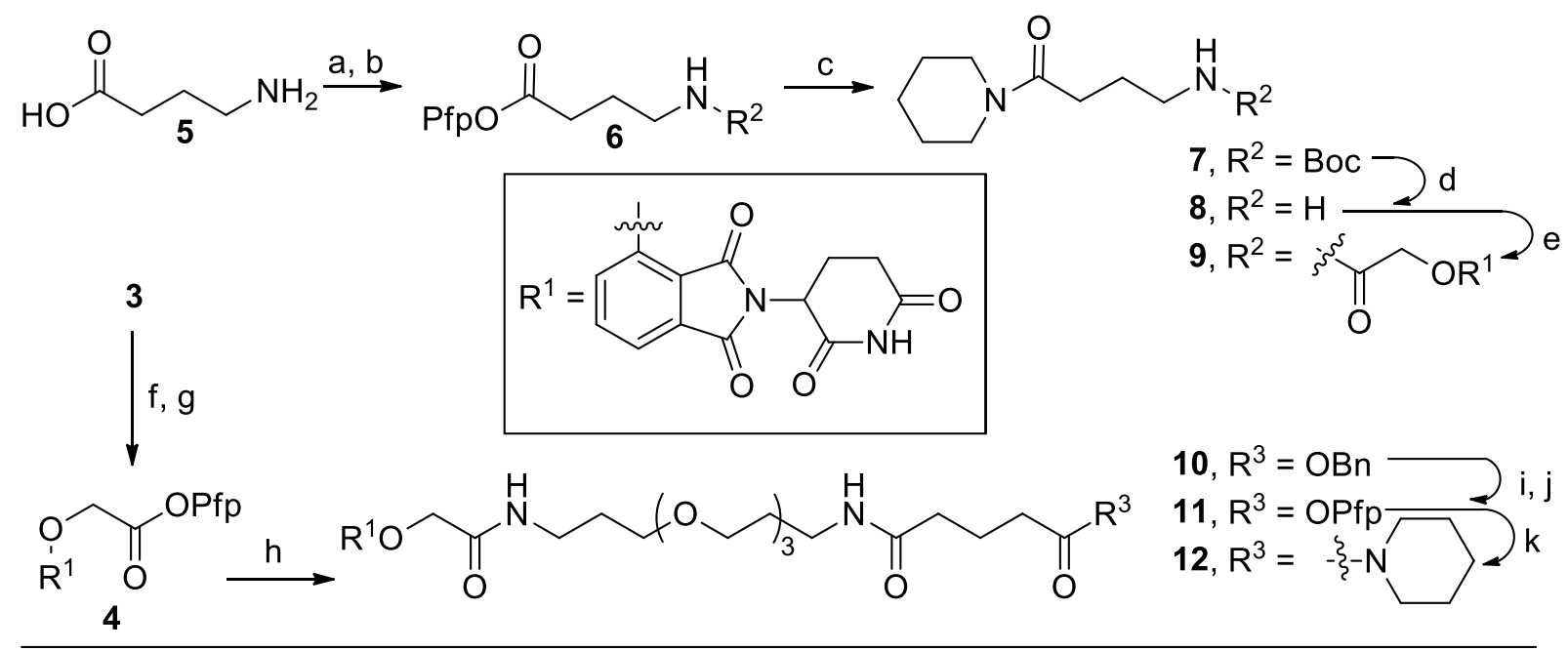<smiles>[R1]OCC(=O)NCCCCS(=O)(=O)N1CCCCC1</smiles>

Scheme 2. Model conjugation of thalidomide linkers with secondary amine model compound - piperidine. a)Boc 20, DMAP, 99\%; b) $\mathrm{CF}_{3} \mathrm{C}(0) \mathrm{OC}_{6} \mathrm{~F}_{5}$, DIPEA, 78\%; c) Piperidine, DIPEA, quantitative; d) TFA, 98\% e) 4, DIPEA, 75\%; f) $\mathrm{H}_{2}$, Pd/C; g) $\mathrm{CF}_{3} \mathrm{C}(\mathrm{O}) \mathrm{OC}_{6} \mathrm{~F}_{5}, \mathrm{DIPEA}_{2}$ 79\% (2 steps); h) $\mathrm{NH}_{2} \mathrm{CH}_{2} \mathrm{CH}_{2} \mathrm{CH}_{2}\left(\mathrm{OCH}_{2} \mathrm{CH}_{2}\right)_{3} \mathrm{CH}_{2} \mathrm{NHC}(\mathrm{O})\left(\mathrm{CH}_{2}\right)_{3} \mathrm{C}(\mathrm{O}) \mathrm{OBn}$, DIPEA, 79\%; i) $\mathrm{H}_{2}$, Pd/C; j) $\mathrm{CF}_{3} \mathrm{C}_{(0) O C} \mathrm{~F}_{5}$, DIPEA, 74\% (2 steps); k) Piperidine, DIPEA, 79\%; l) Potassium phthalimide; m) SOCl 2 22\% (2 steps); n) Piperidine, Et 3 N, 53\%; o) Hydrazine, 94\%; p) 4, DIPEA, 47\%.

Our strategy for coupling conjugate fragments was heavily dependent on the use of pentafluorophenyl (Pfp) esters (Scheme 1, D) in order to form amide bonds, which were chosen specifically for their robust chemical properties. ${ }^{12}$ Several other conjugation techniques, such as click chemistry, ${ }^{13}$ and selective nucleophilic aromatic substitution, ${ }^{2}$ have also been reported in the literature.

The hydroxyl-thalidomide functionality (Scheme 1, A) suffers from poor chemoselectivity in alkylation reactions which make the synthesis of thalidomide conjugates problematic. While $\mathbf{1}$ appears stable under storage, its derivatives suffer from both acidic and basic instability resulting in cleavage of the phthalimide ring. This limitation severely restricts the chemistry compatible for conjugation. The resultant instability dictates which protecting groups could be employed based on the sensitivity of phthalimide ring opening during deprotection conditions. This undesirable reactivity is likely due to the increased electrophilicty of phthalimide carbonyls through hydrogen bonding with the phenolic hydrogen. ${ }^{14}$ This requires the utilization of protecting group chemistry stable to a variety of reactions and yet labile under neutral conditions, leadingus to benzyl esters.

Central to this synthetic strategy was a short and facile synthesis of $\mathbf{3}$ following literature precedent. First, 3hydroxyphthalic anhydride was reacted with 3-amino glutarimide, followed by thalidomide formation using dicyclocarbodiimide (DCC in a 77\% yield. ${ }^{11}$ Phenol 1 was exposed to Mitsunobu reaction conditions to form the benzyl ester linkage onto the thalidomide intermediate to yield $\mathbf{3}$. These initial steps were performed on multi-gram scales. Thalidomide derivative $\mathbf{3}$ was then hydrogenated to quantitatively deprotect the acid over $\mathrm{Pd} / \mathrm{C}$ in DMF (Scheme 2). This reaction was easily monitored using TLC and complete conversion was observed after only one hour. The free acid was then converted to the active Pfp ester $\mathbf{4}$ using pentafluorophenyl trifluoroacetate, the products of which can be easily purified via trituration with diethyl ether. ${ }^{15}$ Pfp ester $\mathbf{4}$ was found to be stable for prolonged storage and was then available for conjugation with a variety of amine containing compounds such as our model piperidine. ${ }^{16}$

First generation linkers consisted of four carbon linkages following a system which had shown promising results in recently published work. ${ }^{1}$ The primary amine of the simple building block, $\gamma$-aminobutyric acid (5) was Boc protected (Scheme 2). The remaining free acid was then transformed to reactive Pfp ester 6 using pentafluorophenyl trifluroacetate. Compound 6 was then coupled to piperidine under basic conditions to afford compound 7. Intermediate $\mathbf{7}$ was exposed to trifluoroacetic acid (TFA) to liberate the terminal amine which was then exposed to $4,{ }^{17}$ affording 9 in 2 hours at ambient temperature. ${ }^{18}$

Our second generation of linkers was designed to investigate the synthetic differences in employing longer linkers with more polar functionalities, inspired by recent publications. 1, 2, 3b, 19 We looked to derivatize the polyethylene glycol (PEG) diamine 4,7,10-trioxa-1,13-tridecanediamine. While this linker was considerably longer than the four carbon alkyl linker, it was inherently much more water soluble.. Succinic anhydride was opened using benzyl alcohol and $\mathrm{NaH}$ to afford a mono-protected diacid. The remaining acid was then converted to an acid chloride in situ. The PEG diamine was first mono-Boc protected and then exposed to the activated acid to afford the desired intermediate consisting of two different protected terminal functionalities. The amine pole was then 


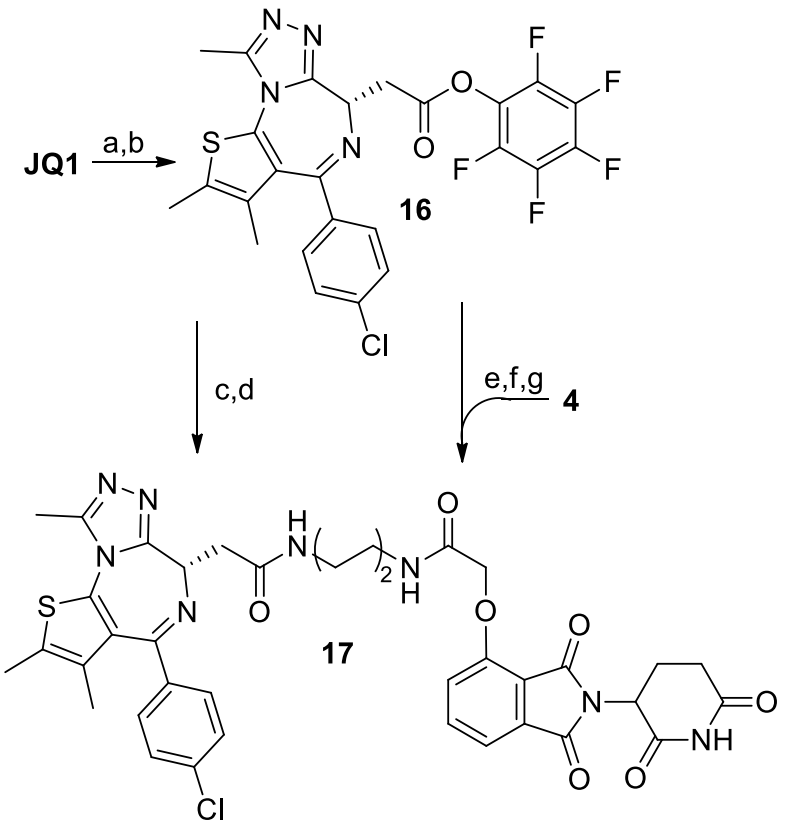

Scheme 3. Syntheses of known PROTAC 17 a) $\mathrm{HCO}_{2} \mathrm{H}$ quantitative; $^{20}$ b) $\mathrm{CF}_{3} \mathrm{C}(\mathrm{O}) \mathrm{OC}_{6} \mathrm{~F}_{5}$, DIPEA, $56 \% \%^{21}$ c) 1,4diaminobutane, DIPEA; d) $\mathbf{4}$, DIPEA, $48 \% ;^{22}$ e) $\mathbf{4}$ $\mathrm{H}_{2} \mathrm{~N}\left(\mathrm{CH}_{2}\right)_{4} \mathrm{NHC}(\mathrm{O}) \mathrm{OC}\left(\mathrm{CH}_{3}\right)_{3}$, DIPEA, 81\%; f) TFA, quantitative; ${ }^{11}$ g) DIPEA, 16, 81\%. ${ }^{23}$

deprotected using TFA, and the newly formed primary amine was reacted with $\mathbf{4}$ to form intermediate $\mathbf{1 0}$ which could also be easily purified by trituration with diethyl ether. The remaining benzyl ester was hydrogenated over Pd/C in two hours to afford the free acid which was exposed to pentafluorophenyl trifluoroacetate to form the respective Pfp ester $\mathbf{1 1}$ in one pot (Scheme 2). Intermediate $\mathbf{1 1}$ was reacted with piperidine to afford conjugate 12 in a $79 \%$ yield. ${ }^{24}$

To expand the scope of linkages beyond simple amide bonds, sulfonamides were also explored. A Gabriel synthesis of 1,4butane sultone (13) was performed, opening the ring to produce a straight chain linker with already established sulfonate and protected amine terminal motifs. The sulfonate salt was then converted to sulfonyl chloride 14, which proved to be stable to flash chromatography (Scheme 2). Previous attempts to open the sultone ring were successfully performed using $\mathrm{NH}_{4} \mathrm{OH}$ to yield a straight chain linker with a free primary amine which was Boc protected. However, attempts at forming the sulfonyl chloride afforded low yields (6\%), due to rapid intramolecular recyclization of the mono-protected amine. The Gabriel synthesis was employed as a means of introducing a doubly protected terminal amine in one step. Sulfonyl chloride $\mathbf{1 4}$ was then exposed to the model reaction conditions with piperidine to afford the desired sulfonamide in moderate yield. The phthalimide ring was then cleaved with hydrazine monohydrate to liberate the free terminal amine, which was reacted with $\mathbf{4}$ to yield conjugate $\mathbf{1 5 . 2 5}$

In order to showcase the versatility of $\mathbf{4}$ in our synthetic strategy we employed this approach to synthesize a PROTAC reported by the Bradner group (Scheme 3). ${ }^{1}$ We developed two novel synthetic routes for forming $\mathbf{1 7}$ via the Pfp ester of JQ1 (16). As this approach minimizes the amount of byproduct formation, this strategy allows purification by flash chromatography instead of HPLC as previously reported. ${ }^{1}$
Conjugates $9, \mathbf{1 2}, \mathbf{1 5}$, and 17 were successfully formed through a synthetic route with clear advantages over previous thalidomide-containing syntheses. One of the most beneficial characteristics of this linker strategy is the use of pentafluorophenyl trifluoroacetate in order to form respective Pfp esters. The ease of purification associated with simple trituration eliminates issues associated with isolation of highly polar compounds. In addition to the ease of synthesis and purification, this linker strategy can easily be tailored to accommodate a broad scope of targeting molecules. The adaptability of this synthetic strategy lends itself to the diverse linkers required for PROTAC synthesis. By varying the length, hydrophobic properties, as well as linkage identity we have developed a strategy for conjugating a broad scope of target molecules through a variety of functional groups. In vitro structure activity relationship studies are currently underway.

\section{Funding Information}

This work was funded by the Multiple Myeloma Research Foundation, NSERC, the University of Calgary, Alberta Children's Hospital Foundation and Research Institute, and the Charbonneau Cancer Institute.

\section{Supporting Information}

YES

\section{Primary Data}

NO

\section{References and Notes}

(1) Winter, G.E.; Buckley, D.L.; Paulk, J.; Roberts, J.M.; Souza, A.; DhePaganon, S.; Bradner, J.E. Science 2015, 348, 1376.

(2) Lu, J.; Qian, Y.; Altieri, M.; Dong, H.; Wang, J.; Raina, K.; Hines, J.; Winkler, J.D.; Crew, A.P.; Coleman, K.; Crews, C.M. Chem. Biol. 2015, 22, 755.

(3) (a) Fischer, E.S.; Bohm, K.; Lydeard, J.R.; Yang, H.; Stadler, M.B.; Cavadini, S.; Nagel, J.; Serluca, F.; Acker, V.; Lingaraju, G.M.; Tichkule, R.B., Schebesta, M.; Forrester, W.C.; Schirle, M.; Hassiepen, U.; Ottl, J.; Hild, M.; Beckwith, R.E.J.; Harper, J.W.; Jenkins, J.L.; Thoma, N.H. Nature 2014, 512, 49. (b) Lebraud, H.; Wright, D.J.; Johnson, C.N.; Heightman, T.D. ACS Cent. Sci. 2016, 2, 927.

(4) Long, M.J.C.; Poganik, J.R.; Aye, Y.J. Am. Chem. Soc. 2016, 138, 3610.

(5) Srinivasarao, M.; Galliford, C.V.; Low, P.S. Nat. Rev. Drug Discov. 2015, 14, 203.

(6) DeRose, R.; Miyamoto, T.; Inoue, T. Pfluegers Arch. 2013, 465, 409.

(7) Corson, T.W.; Aberle, N.; Crews, C.M.; ACS Chem. Biol. 2008, 3, 677.

(8) Lai, A.C.; Crews, C.M. Nat. Rev. Drug Discov. 2017, 16, 101.

(9) (a) Remillard, D.; Buckley, D.L.; Paulk, J.; Brien, G.L.; Sonnett, M.; Seo, H-S.; Dastjerdi, S.; Wühr, M.; Dhe-Paganon, S.; Armstrong, S.A.; Bradner, J.E. Angew. Chem. Int. Ed. 2017, 56, 5738. (b) Schiedel, M.; Herp, D.; Hammelmann, S.; Swyter, S.; Lehotzky, A.; Robaa, D.; Oláh, J.; Ovádi, J.; Sippl, W.; Jung, M. J. Med. Chem. [Online early access]. DOI: 10.1021/acs.jmedchem.6b01872. Published Online: Apr 5, 2017. (c) Lai A.C.; Toure, M.; Hellerschmied, D.; Salami, J.; JaimeFigueroa, S.; Ko, E.; Hines, J.; Crews, C.M. Angew. Chem. Int. Ed. 2016, 55, 807.

(10) Gladysz, J. A.; Lee, S. J.; Tomasello, J. A. V.; Yu, Y. S. J. Org. Chem. 1977, 42, 4170.

(11) Lohbeck, J.; Miller, A.K. Bioorg. Med. Chem. Lett. 2016, 26, 5260.

(12) Montalbetti, C. A. G. N.; Falque, V. Tetrahedron 2005, 61, 10827.

(13) Wurz, R.P.; Dellamaggiore, K.; Dou, H.; Javier, N.; Lo M-C.; McCarter, J.D.; Mohl, D.; Sastri, C.; Lipford, J.R.; Cee, V.J. J. Med. Chem. [Online early access]. DOI: 10.1021/acs.jmedchem.6b01781. Published Online: Apr 5, 2017. 
(14) Orchin, M.; Macomber, R.S.; Pinhas, A.R.; Wilson, R.M. The Vocabulary and Concepts of Organic Chemistry, $2^{\text {nd }}$ Ed.; John Wiley \& Sons: Hoboken, 2005.

\section{(15) General Procedure for the Synthesis of 4}

A solution of $3(0.691 \mathrm{~g}, 1.64 \mathrm{mmol})$ in DMF (15 mL) was stirred with $(\mathrm{Pd} / \mathrm{C}(0.04 \mathrm{~g}, 10 \mathrm{~mol} \%)$ under hydrogen for $1.5 \mathrm{~h}$, filtered and concentrated in vacuo. The crude product $(0.148 \mathrm{~g}, 0.45 \mathrm{mmol})$ was then redissolved in DMF ( $6 \mathrm{~mL}$ ), and DIPEA (0.118 g, $0.16 \mathrm{~mL}$, $0.92 \mathrm{mmol}$ ) was added with stirring and the solution was cooled to $0{ }^{\circ} \mathrm{C}$. Pentafluorophenyl trifluoroacetate $(0.187 \mathrm{~g}, 0.12 \mathrm{~mL}, 0.67$ $\mathrm{mmol}$ ) was then added with stirring. The reaction mixture was allowed to come to ambient temperature for $2 \mathrm{~h}$. The mixture was concentrated in vacuo, and purified by trituration with diethyl ether to afford $0.175 \mathrm{~g} \mathrm{(79 \% )} \mathrm{of} 4$.

${ }^{1} \mathrm{H}$ NMR $\left(400 \mathrm{MHz}, \mathrm{CDCl}_{3}\right) \delta 7.99(\mathrm{~s}, 1 \mathrm{H}), 7.76(\mathrm{dd}, J=8.4,7.3 \mathrm{~Hz}$, $1 \mathrm{H}), 7.63(\mathrm{dd}, J=7.4,0.7 \mathrm{~Hz}, 1 \mathrm{H}), 7.26(\mathrm{dd}, J=8.5,0.8 \mathrm{~Hz}, 1 \mathrm{H}), 5.34$ (d, $J=1.4 \mathrm{~Hz}, 2 \mathrm{H}), 5.04-4.97(\mathrm{~m}, 1 \mathrm{H}), 2.98-2.74(\mathrm{~m}, 3 \mathrm{H}), 2.22-$ $2.14(\mathrm{~m}, 1 \mathrm{H})$. HRMS (ESI) $\mathrm{m} / \mathrm{z}$ calc. for $\left[\mathrm{C}_{21} \mathrm{H}_{11} \mathrm{~F}_{5} \mathrm{~N}_{2} \mathrm{O}_{7}+\mathrm{Na}\right]^{+}=$ 521.0379 , found 521.0368

(16) No decomposition observed after 5 weeks at $-20^{\circ} \mathrm{C}$.

(17) General Procedure for Coupling to 4

To a solution of corresponding free amine (1 equiv.) in DMF, was added DIPEA (3 equiv.) under stirring. A solution of 4 (1.1 equiv.) in $\mathrm{DMF}$ was added to the reaction mixture at ambient temperature. After $2 \mathrm{~h}$ the mixture was concentrated in vacuo and purified by silica gel flash chromatography to afford the title compound.

(18) 2-((2-(2,6-dioxopiperidin-3-yl)-1,3-dioxoisoindolin-4yl)oxy)-N-(4-oxo-4-(piperidin-1-yl)butyl)acetamide (9) Purified by silica gel flash chromatography $\left(5 \% \mathrm{MeOH}\right.$ in $\left.\mathrm{CHCl}_{3}\right)$ to afford $0.119 \mathrm{~g}(75 \%)$ as a colourless oil. ${ }^{1} \mathrm{H}$ NMR $\left(400 \mathrm{MHz}, \mathrm{CDCl}_{3}\right)$ $\delta 8.70(\mathrm{~s}, 1 \mathrm{H}), 7.75(\mathrm{dd}, J=8.4,7.3 \mathrm{~Hz}, 1 \mathrm{H}), 7.71(\mathrm{t}, J=5.6 \mathrm{~Hz}, 1 \mathrm{H})$, $7.57(\mathrm{dd}, J=7.4,0.7 \mathrm{~Hz}, 1 \mathrm{H}), 7.23(\mathrm{dd}, J=8.5,0.7 \mathrm{~Hz}, 1 \mathrm{H}), 5.00-$ $4.92(\mathrm{~m}, 1 \mathrm{H}), 4.73-4.60$ (m, 2H), $3.58-3.52$ (m, 2H), 3.45 (ddd, $J$ $=14.7,7.4,6.0 \mathrm{~Hz}, 1 \mathrm{H}), 3.41-3.33(\mathrm{~m}, 3 \mathrm{H}), 2.98-2.70(\mathrm{~m}, 3 \mathrm{H})$, $2.42-2.36(\mathrm{~m}, 2 \mathrm{H}), 2.22-2.15(\mathrm{~m}, 1 \mathrm{H}), 1.97-1.88(\mathrm{~m}, 2 \mathrm{H}), 1.66-$ $1.60(\mathrm{~m}, 2 \mathrm{H}), 1.59-1.49(\mathrm{~m}, 4 \mathrm{H}) .{ }^{13} \mathrm{C}$ NMR (400 MHz, $\left.\mathrm{CDCl}_{3}\right) \delta$ $170.80,170.42,168.04,166.89,166.54,154.97,137.01,133.61$, $120.51,118.56117 .68,77.20,69.00,49.42,46.61,42.78,39.12$, $31.34,30.66,26.48,25.55,24.84,24.54,22.73$. HRMS (ESI) m/z calc. for $\left[\mathrm{C}_{24} \mathrm{H}_{28} \mathrm{~N}_{4} \mathrm{O}_{7}+\mathrm{H}\right]^{+}=485.2031$, found 485.2047 .

(19) Lu, J.; Qian, Y.; Altieri, M.; Dong, H.; Wang, J.; Raina, K.; Hines, J.; Winkler, J.D.; Crew, A.P.; Coleman, K.; Crews, C.M.; Chem. Biol. 2015, $22,755$.

(20) 2-(4-(4-chlorophenyl)-2,3,9-trimethyl-6H-thieno[3,2f] $[1,2,4]$ triazolo[4,3-a][1,4]diazepin-6-yl)acetic acid (JQ1Acid)

JQ1 (0.05g, $0.1099 \mathrm{mmol})$ was dissolved in formic acid (4.5 $\mathrm{mL})$ and stirred for 4 days. The solvent was removed in vacuo to afford a fine yellow powder. The product was used without purification.

(21) perfluorophenyl 2-(4-(4-chlorophenyl)-2,3,9-trimethyl-6Hthieno[3,2-f][1,2,4]triazolo[4,3-a][1,4]diazepin-6-yl)acetate (16)

To a solution of JQ1-Acid ( $0.055 \mathrm{~g}, 0.136 \mathrm{mmol})$ in DMF ( $2 \mathrm{~mL})$ was added DIPEA ( $0.17 \mathrm{~mL}, 0.123 \mathrm{~g}, 0.952 \mathrm{mmol})$ and pentaflurophenyl trifluoroacetate $(0.05 \mathrm{~mL}, 0.076 \mathrm{~g}, 0.272 \mathrm{mmol})$. The solution was stirred for 1 hour and solvent was removed in vacuo. The residue was purified by silica gel flash chromatography (1:1:1 EtOAc:Hexanes:THF) to afford $0.0432 \mathrm{~g} \mathrm{(56 \% )}$ as a yellow oil. ${ }^{1} \mathrm{H}$ NMR (400 MHz, $\left.\mathrm{CDCl}_{3}\right) \delta 7.49-7.34(\mathrm{~m}, 4 \mathrm{H}), 4.71(\mathrm{dd}, J=9.5,4.6$ $\mathrm{Hz}, 1 \mathrm{H}), 4.08(\mathrm{dd}, J=16.9,9.5 \mathrm{~Hz}, 1 \mathrm{H}), 3.91(\mathrm{dd}, J=16.9,4.6 \mathrm{~Hz}, 1 \mathrm{H})$, $2.73(\mathrm{~s}, 3 \mathrm{H}), 2.45(\mathrm{~d}, J=0.9 \mathrm{~Hz}, 3 \mathrm{H}), 1.73(\mathrm{~d}, J=0.9 \mathrm{~Hz}, 3 \mathrm{H}) .{ }^{13} \mathrm{C} \mathrm{NMR}$ $\left(151 \mathrm{MHz}, \mathrm{CDCl}_{3}\right) \delta 167.62,164.38,154.65,150.13,141.90140 .26$, $138.70,137.03,136.30,132.22,131.00,130.97,130.26,129.83$, $128.76,53.57,36.39,14.40,13.11,11.85$. HRMS (MALDI) m/z calc for $\left[\mathrm{C}_{25} \mathrm{H}_{16} \mathrm{ClF}_{5} \mathrm{~N}_{4} \mathrm{O}_{2} \mathrm{~S}+\mathrm{H}\right]^{+}=567.0675$, found 567.0771.

(22) 2-(4-(4-chlorophenyl)-2,3,9-trimethyl-6H-thieno[3,2f] [1,2,4]triazolo[4,3-a][1,4]diazepin-6-yl)-N-(4-(2-((2-(2,6dioxopiperidin-3-yl)-1,3-dioxoisoindolin-4yl)oxy)acetamido)butyl)acetamide (17)
To a solution of 1,4-diaminobutane $(0.03 \mathrm{~g}, 0.371 \mathrm{mmol}$ ) in DMF (2 $\mathrm{mL})$ was added DIPEA (0.065 mL, $0.048 \mathrm{~g}, 0.371 \mathrm{mmol})$ and 16 $(0.021 \mathrm{~g}, 0.0371 \mathrm{mmol})$ and was stirred for 1.5 hours. The mixture was concentrated in vacuo and re-dissolved in DMF $(1 \mathrm{~mL})$. DIPEA ( $0.026 \mathrm{~mL}, 0.019 \mathrm{~g}, 0.0148 \mathrm{mmol}$ ) and 4 (0.028 g, $0.0557 \mathrm{mmol})$ was added and stirred overnight, The mixture was concentrated in vacuo and purified by silica gel flash chromatography (5\% to $10 \%$ $\mathrm{MeOH}$ in $\mathrm{CHCl}_{3}$ ) to afford $0.014 \mathrm{~g} \mathrm{(48 \% )} \mathrm{of} \mathrm{the} \mathrm{title} \mathrm{compound} \mathrm{as} \mathrm{a}$ mixture of diastereomers. ${ }^{1} \mathrm{H}$ NMR (600 MHz, MeOD) $\delta 8.34-8.29$ $(* \mathrm{~m}, 1 \mathrm{H}), 8.12\left({ }^{*} \mathrm{q}, J=5.7 \mathrm{~Hz}, 1 \mathrm{H}\right), 7.80(\mathrm{dd}, J=8.4,7.3 \mathrm{~Hz}, 1 \mathrm{H}), 7.52$ (d, $J=7.3 \mathrm{~Hz}, 1 \mathrm{H}$ ), $7.45-7.38(\mathrm{~m}, 5 \mathrm{H}), 5.10$ (ddd, $J=12.4,5.5,3.1$ $\mathrm{Hz}, 1 \mathrm{H}$ ), 4.77 (d, J=1.7 Hz, 2H), 4.63 (ddd, $J=9.1,5.4,1.1 \mathrm{~Hz}, 1 \mathrm{H}$ ), $3.44-3.32$ (m, 4H), $3.30-3.25(\mathrm{~m}, 2 \mathrm{H}), 2.86-2.77(\mathrm{~m}, 1 \mathrm{H}), 2.73-$ $2.65(\mathrm{~m}, 5 \mathrm{H}), 2.43(\mathrm{~d}, J=2.5 \mathrm{~Hz}, 3 \mathrm{H}), 2.10$ (dddd, $J=10.7,8.0,4.9$, $2.6 \mathrm{~Hz}, 1 \mathrm{H}), 1.70-1.60(\mathrm{~m}, 7 \mathrm{H}){ }^{*}$ exchangeable protons. ${ }^{13} \mathrm{NMR}$ $\left(151 \mathrm{MHz}, \mathrm{CDCl}_{3}\right) \delta 174.4,172.77,172.68,171.30,171.27,169.91$, $168.24,167.79,166.24,166.21,157.00,156.29,152.19,138.23$ $138.09,137.95,134.87,133.53,133.18,132.04,132.02,131.96$, $131.31,129.78,121.90,121.87,119.37,118.00,69.57,69.55$, $55.23,50.55,50.54,40.21,40.19,40.09,40.06,39.84,38.88,38.86$, $32.14,32.12,27.77,27.66,27.64,23.63,23.61,14.41,12.92,11.62$. HRMS (MALDI) m/z calc. for $\left[\mathrm{C}_{38} \mathrm{H}_{37} \mathrm{ClN}_{8} \mathrm{O}_{7} \mathrm{~S}+\mathrm{H}\right]^{+}=785.2267$, found 785.2232 .

(23) 2-(4-(4-chlorophenyl)-2,3,9-trimethyl-6H-thieno[3,2f] $[1,2,4]$ triazolo[4,3-a][1,4]diazepin-6-yl)-N-(4-(2-((2-(2,6dioxopiperidin-3-yl)-1,3-dioxoisoindolin-4yl)oxy)acetamido)butyl)acetamide (17)

To a solution of the free amine 4-linker $(0.021 \mathrm{~g}, 0.052 \mathrm{mmol})$ in DMF $(1.5 \mathrm{~mL})$ was added DIPEA (0.09 mL, $0.067 \mathrm{~g}, 0.5 \mathrm{mmol})$ and 16 $(0.022 \mathrm{~g}, 0.039 \mathrm{mmol})$ and stirred overnight. The reaction mixture was stirred with potassium carbonate $(0.021 \mathrm{~g})$ for 30 minutes, filtered, concentrated in vacuo and purified by silica gel flash chromatography (5\% to $10 \% \mathrm{MeOH}$ in $\mathrm{CHCl}_{3}$ ) to afford $0.025 \mathrm{~g}$ $(81 \%)$ of the title compound as a mixture of diastereomers. Data identical to reference 22.

(24) N-(1-((2-(2,6-dioxopiperidin-3-yl)-1,3-dioxoisoindolin-4yl)oxy)-2-oxo-7,10,13-trioxa-3-azahexadecan-16-yl)-4-oxo-4(piperidin-1-yl)butanamide (12)

Purified by flash chromatography $\left(5 \% \mathrm{MeOH}\right.$ in $\left.\mathrm{CHCl}_{3}\right)$ to afford $0.011 \mathrm{~g}(79 \%)$ as a colourless oil. ${ }^{1} \mathrm{H}$ NMR $\left(600 \mathrm{MHz}, \mathrm{CDCl}_{3}\right) \delta 9.43$ (s, $1 \mathrm{H}), 7.74(\mathrm{dd}, J=8.4,7.4 \mathrm{~Hz}, 1 \mathrm{H}), 7.60(\mathrm{t}, J=5.8 \mathrm{~Hz}, 1 \mathrm{H}), 7.55$ (dd, $J=7.5,0.7 \mathrm{~Hz}, 1 \mathrm{H}), 7.21(\mathrm{dd}, J=8.4,0.6 \mathrm{~Hz}, 1 \mathrm{H}), 6.66$ (t, $J=5.6$ $\mathrm{Hz}, 1 \mathrm{H}), 5.03-4.96(\mathrm{~m}, 1 \mathrm{H}), 4.65(\mathrm{~d}, J=2.7 \mathrm{~Hz}, 2 \mathrm{H}), 3.67-3.64(\mathrm{~m}$, $4 \mathrm{H}), 3.64-3.61(\mathrm{~m}, 2 \mathrm{H}), 3.58(\mathrm{tt}, J=6.5,2.7 \mathrm{~Hz}, 3 \mathrm{H}), 3.53(\mathrm{td}, J=$ $5.7,1.8 \mathrm{~Hz}, 4 \mathrm{H}), 3.50-3.44(\mathrm{~m}, 2 \mathrm{H}), 3.43-3.39(\mathrm{~m}, 2 \mathrm{H}), 3.31$ (qd, $J$ $=6.4,4.9 \mathrm{~Hz}, 2 \mathrm{H}), 2.91-2.75(\mathrm{~m}, 3 \mathrm{H}), 2.66(\mathrm{td}, J=6.7,1.3 \mathrm{~Hz}, 2 \mathrm{H})$, $2.49(\mathrm{t}, J=6.8 \mathrm{~Hz}, 2 \mathrm{H}), 2.18-2.13(\mathrm{~m}, 1 \mathrm{H}), 1.87(\mathrm{p}, J=6.4 \mathrm{~Hz}, 2 \mathrm{H})$, $1.82(\mathrm{~s}, 1 \mathrm{H}), 1.75(\mathrm{q}, J=6.3 \mathrm{~Hz}, 2 \mathrm{H}), 1.62(\mathrm{td}, J=6.9,4.9 \mathrm{~Hz}, 2 \mathrm{H})$, $1.58-1.48(\mathrm{~m}, 4 \mathrm{H}) .{ }^{13} \mathrm{C}$ NMR $\left(600 \mathrm{MHz}, \mathrm{CDCl}_{3}\right) \delta 172.57,171.34$ $170.13,168.33,166.69,166.62,154.61,136.93,133.62,119.68$, $117.33,70.41,70.40,70.15,70.06,69.39,68.73,68.22,49.35$, 46.40, 42.90, 37.31, 36.49, 31.59, 31.46, 29.23, 28.97, 28.80, 26.30, $25.54,24.48,22.69$. HRMS (ESI) $\mathrm{m} / \mathrm{z}$ calc. for $\left[\mathrm{C}_{34} \mathrm{H}_{47} \mathrm{~N}_{5} \mathrm{O}_{11}+\mathrm{Na}\right]^{+}=$ 724.3163 , found 724.3168 .

(25) 2-((2-(2,6-dioxopiperidin-3-yl)-1,3-dioxoisoindolin-4yl)oxy)-N-(4-(piperidin-1-ylsulfonyl)butyl)acetamide (15) Purified by flash chromatography $\left(5 \% \mathrm{MeOH}\right.$ in $\left.\mathrm{CHCl}_{3}\right)$ to afford $0.016 \mathrm{~g} \mathrm{(47 \% )}$ as a white solid. ${ }^{1} \mathrm{H}$ NMR $\left(400 \mathrm{MHz}, \mathrm{CDCl}_{3}\right) \delta 8.08(\mathrm{~s}$, $1 \mathrm{H}), 7.75(\mathrm{dd}, J=8.4,7.4 \mathrm{~Hz}, 1 \mathrm{H}), 7.67(\mathrm{~s}, 1 \mathrm{H}), 7.56(\mathrm{dd}, J=7.3,0.7$ $\mathrm{Hz}, 1 \mathrm{H}$ ), 7.20 (dd, J = 8.4, 0.7 Hz, 1H), $5.05-4.98(\mathrm{~m}, 1 \mathrm{H}), 4.65$ (d, $J$ $=2.3 \mathrm{~Hz}, 2 \mathrm{H}), 3.43$ (sept, $J=6.9 \mathrm{~Hz}, 2 \mathrm{H}), 3.29-3.12(\mathrm{~m}, 4 \mathrm{H}), 2.97-$ $2.89(\mathrm{~m}, 3 \mathrm{H}), 2.89-2.71(\mathrm{~m}, 2 \mathrm{H}), 2.23-2.14(\mathrm{~m}, 1 \mathrm{H}), 1.99-1.87$ $(\mathrm{m}, 2 \mathrm{H}), 1.74(\mathrm{dt}, J=14.4,6.9 \mathrm{~Hz}, 2 \mathrm{H}), 1.67-1.53(\mathrm{~m}, 6 \mathrm{H}) \cdot{ }^{13} \mathrm{C} \mathrm{NMR}$ $\left(400 \mathrm{MHz}, \mathrm{CDCl}_{3}\right) \delta 170.82,168.00,166.95,166.55,154.65,137.10$, 133.55, 120.08, 118.46, 117.64, 77.21, 68.49, 49.38, 48.51, 46.64, $38.44,31.40,28.27,25.67,23.81,22.57,20.55$. HRMS (ESI) m/z calc. for $\left[\mathrm{C}_{24} \mathrm{H}_{30} \mathrm{~N}_{4} \mathrm{O}_{8} \mathrm{~S}+\mathrm{H}\right]^{+}=535.1857$, found 535.1853 . 
